\title{
Thermo-Catalytic Pyrolysis of Waste Plastics from End of Life Vehicle
}

\author{
Norbert Miskolczi ${ }^{1, a}$, Zsuzsanna Czégény $^{2}$ \\ ${ }^{1}$ Chemical Engineering and Process Engineering Institute, MOL Department of Hydrocarbon and Coal Processing, University of Pannonia, \\ Veszprém, 10 Egyetem u., 8200, Hungary \\ ${ }^{2}$ Institute of Materials and Environmental Chemistry, Research Centre for Natural Sciences, Hungarian Academy of Sciences, Budapest \\ 1117 Magyar Tudósok krt. 2, Hungary
}

\begin{abstract}
Pyrolysis of waste plastics is widely used recycling method. Owing to the end-of-life vehicles regulations, $95 \%$ of passenger cars and vehicles must reused/recovered after the dismantling. Pyrolysis of waste polyethylene and polypropylene obtained from end-of-life vehicles was investigated in a continuously stirred batch reactor using 500 and $600^{\circ} \mathrm{C}$ temperatures. To ensure the pyrolysis reactions the tested catalysts $(5 \%$ of ZSM-5, HZSM-5, Ni-ZSM- 5 and Fe-ZSM-5) were added directly to the mixtures of raw materials. Products of pyrolysis were separated into gases, pyrolysis oil and heavy oil, which was further analyzed by gas-chromatography, Fourier transformed infrared spectroscopy and other standardized methods. Based on the results it was concluded, that the catalysts significantly increase the yields of volatile products, and modify their composition. Especially the alkane/alkene ratio, the methane concentration and the concentration of branched hydrocarbon could be affected by the applied catalysts. Ni-ZSM- 5 catalyst had the highest activity in methane production, while HZSM-5 catalyst proved effective in isomerization reactions. Using H-ZSM-5, Ni-ZSM-5, and Fe-ZSM-5 catalyst notably decreased average molecular weight of pyrolysis oils and significantly higher aromatic content was observed.
\end{abstract}

\section{Introduction}

Waste polymers could be transformed into valuable hydrocarbons by pyrolysis. The effect of the process parameters to the product properties is well published [15]. E.g. higher gas and oil yields are obtained using higher temperature and catalyst. Another important parameter is the kind of raw material, because it has a dominant effect on the product yield and compositions. Based on references, especially the decomposition of virgin polymers was investigated and less information is available related to the pyrolysis of real wastes.

Modern cars and vehicles contain approximately 10$15 \%$ plastics, depending on their type. Regarding the type of plastics, both mass plastics and engineering plastics are widespread used in automotive sector. Especially polyethylene, polypropylene, polyamide, polyurethane, acrylonitrile butadiene styrene, etc. are used. Figure 1 demonstrates the average composition of parts of vehicles [6-8]. In general, the further utilization of metal and glass content of the vehicles are solved problem, however the long time sustainable plastic utilization is an open question. Regarding waste plastics from ELV, polyethylene, polypropylene and polystyrene are the mostly favored for pyrolysis, because the chemical structure build up only from carbon and hydrogen; therefore their pyrolysis oil also free of unwanted components.

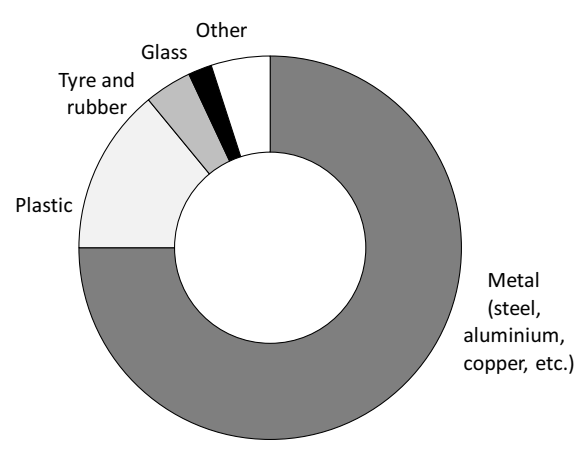

Figure 1. Average composition of vehicle parts.

Based on references, especially the pyrolysis of waste oils and tires from automotive sector are investigated. It was concluded, that both tires and waste oils should be advantageously used for hydrocarbon or energy production [9-11]. However aromatics, polyaromatics or even contaminants, such as sulfur in case of waste tire pyrolysis can cause serious problems during further utilization. Results of the investigation of the pyrolysis of waste plastics from automotive industry using pyrolysisgas chromatography/mass spectrometry were published recently, which looks an attractive method for investigation of small amount of samples [12-14].

In our current work larger amount of waste polyethylene and polypropylene mixture from ELV was pyrolyzed using different catalysts (ZSM-5, HZSM-5, Ni-

\footnotetext{
${ }^{\mathrm{a}}$ Corresponding author: mnorbert@almos.uni-pannon.hu
} 
ZSM-5 and Fe-ZSM-5) in a continuously stirred batch reactor using 500 and $600^{\circ} \mathrm{C}$ temperature.

\section{Material and methods}

\subsection{Raw materials}

Waste high density polyethylene (HDPE), low density polyethylene (LDPE) and polypropylene (PP) were used as raw materials in our current work from ELV dismantling. ELV wastes contained $4.85 \%$ ash, especially glass fiber and $2.17 \%$ volatiles, therefore the combustibles were $92.98 \%$.

Different catalysts were used for modifying the pyrolysis characteristic and properties of the products: ZSM-5, HZSM-5, Ni-ZSM-5 and Fe-ZSM-5. Wet impregnation was used for Ni-ZSM-5 and Fe-ZSM-5 synthesis, using $\mathrm{Ni}\left(\mathrm{NO}_{3}\right)_{2} \cdot 6 \mathrm{H}_{2} \mathrm{O}$ and $\mathrm{Fe}\left(\mathrm{NO}_{3}\right)_{3} \cdot 9 \mathrm{H}_{2} \mathrm{O}$, respectively, while $1 \mathrm{M} \mathrm{NH} \mathrm{NO}_{3}$ was used for HZSM-5 synthesis at $80^{\circ} \mathrm{C}$. Catalysts were dried for 10 hours at $110^{\circ} \mathrm{C}$, and then each of them was calcined at $600^{\circ} \mathrm{C}$ for 3 hours.

\subsection{Apparatus for waste plastic pyrolysis}

A stainless steel continuously stirred batch reactor was used for pyrolysis of waste plastics from ELV using temperatures of 500 and $600^{\circ} \mathrm{C}$. The schematic layout of the pyrolysis rig is shown in Figure 2.

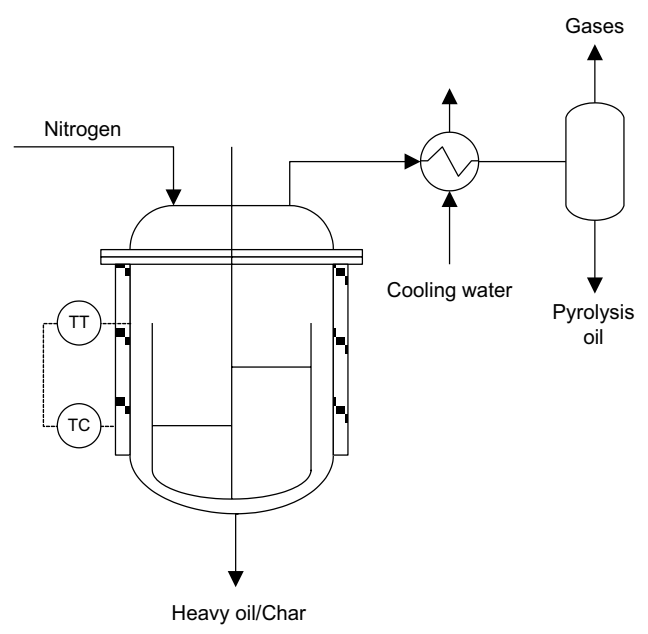

Figure 2. Batch apparatus for ELV waste plastic pyrolysis.

$300 \mathrm{~g}$ of raw materials and $5 \%$ of catalysts were weighted into the reactor. Then the reactor top section was placed and valve for nitrogen flush was opened. The temperature increased to the set value in 15 minutes. The temperature was measured on the reactor wall and controlled by a computer programmed controller. Mixtures of the decomposed hydrocarbons went through a condenser and then it was separated into gaseous and pyrolysis oil for further analysis.
Gases were analyzed by DANI GC using $50 \mathrm{~m} \times 0.32$ mm fused silica column with $\mathrm{Al}_{2} \mathrm{O}_{3} / \mathrm{KCl}$ coating.

Pyrolysis oils were also analyzed by gaschromatography using a $30 \mathrm{~m} \quad \mathrm{x} \quad 0.32 \mathrm{~mm} \quad$ Rtx ${ }^{\circledR}-1$ (nonpolar phase; Crossbond ${ }^{\circledR}$ dimethyl polysiloxane) column.

The saturated/unsaturated ratio of the oils was followed by a TENSOR 27 type FTIR spectrometer (resolution: $2 \mathrm{~cm}^{-1}$, illumination: $\mathrm{SiC}$ Globar light, monocromator: Littrow prism, detector: RT-DLaTGS (Deutero L- $\alpha$-Alanine Triglycin-Sulphate) type detector with $\mathrm{KBr}$ window) in the $4000-400 \mathrm{~cm}^{-1}$ wave number ranges.

Volatile characteristic of pyrolysis oil was determined by Engler distillation test (ASTM-D 1078), while the density was measured according to MSZ EN ISO 12185 standard.

Heavy oil fractions were analyzed by the following methods: flash point determination (ISO 2719:2002 and MSZ 15967:1979), determination viscosity (MSZ ISO 3105:1998), melting point determination (MSZ 3252:1973), density measurement (MSZ EN 1285:1996), and heating value (MSZ 24000-5:1978).

\section{Results and discussion}

\subsection{Product yields}

Gases, pyrolysis oil and heavy oil (together with solid char) had been obtained from pyrolysis experiments; product yields are shown in Figure 3/a and b.

Based on results, it is clear, that higher yields of gases and pyrolysis oil were obtained at higher temperature using 15 min reaction time, than that of at lower temperature after $25 \mathrm{~min}$ pyrolysis, which was attributed to the higher thermal stability of C-C bonds at lower temperature. Catalysts also had a significant effect to the yields of product. Each of them could increase both the gaseous and pyrolysis oil yields.

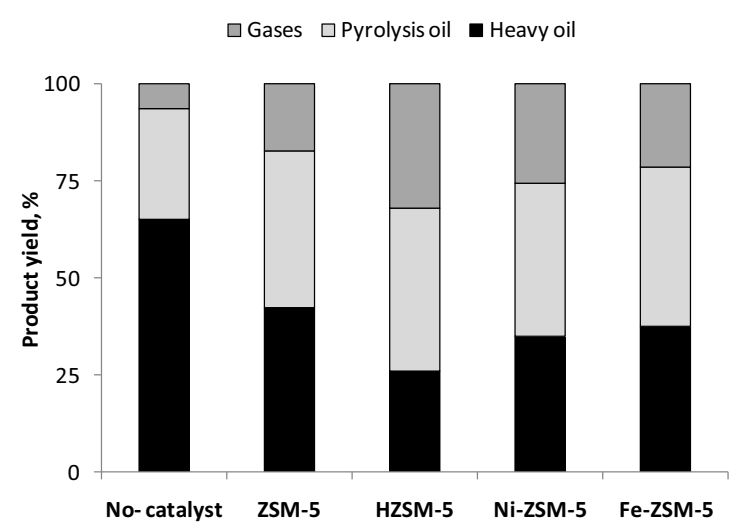

Figure 3/a. Product yields obtained at $500^{\circ} \mathrm{C}$ after $25 \mathrm{~min}$ reaction time.

\subsection{Methods}




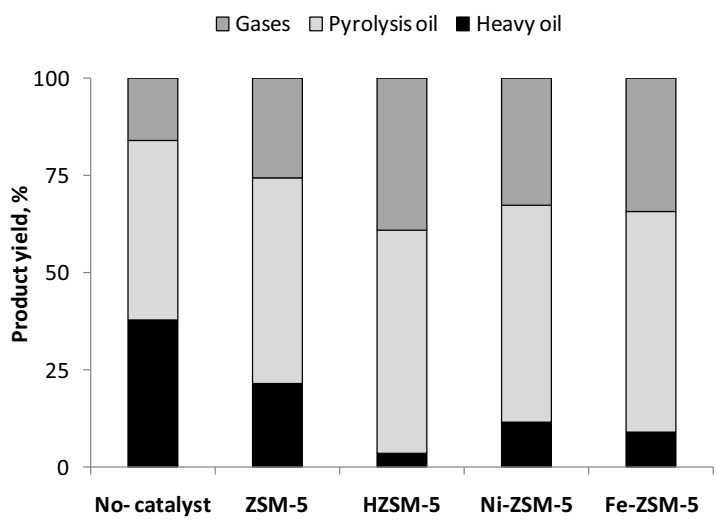

Figure $3 / \mathbf{b}$. Product yields at $600^{\circ} \mathrm{C}$ after $15 \mathrm{~min}$ reaction time.

The summarized yields of gases and pyrolysis oil was $34.7 \%$ and $62.2 \%$ at $500^{\circ}$ (after $25 \mathrm{~min}$.) and $600^{\circ} \mathrm{C}$ (after $15 \mathrm{~min}$.), respectively. HZSM-5 catalyst showed the highest activity in yield increasing of gases and pyrolyis oil. The yield of pyrolysis oil was $40.3 \%$ and $17.2 \%$ gases were found at $500^{\circ} \mathrm{C}$ or $52.7 \%$ pyrolysis oil and $25.7 \%$ gases at $600^{\circ} \mathrm{C}$ using ZSM-5 catalyst. Both could be further increase using HZSM-5 catalyst, from 17.2\% to $31.8 \%$ at $500^{\circ} \mathrm{C}$ and from $15.9 \%$ to $25.7 \%$ at $600^{\circ} \mathrm{C}$ in case of gases, while only $2-5 \%$ increasing was measured regarding pyrolysis oil using HZSM-5. It means that the protonated form of ZSM-5 catalyst had activity especially in increasing of gaseous products, which was the consequence of the relatively small pore size and large microporous surface are of ZSM-5 zeolite structure. NiZSM-5 and Fe-ZSM-5 had similar affect on the yields of gases and pyrolysis oil as ZSM-5 catalyst, but the yield of gaseous products was higher $\left(25.6 \%\right.$ and $21.3 \%$ at $500^{\circ} \mathrm{C}$ and $32.5 \%$ and $34.2 \%$ at $600^{\circ} \mathrm{C}$ ). Results also well show, that the volatile yield was higher at lower temperature, than that of using higher pyrolysis temperature, in case of each investigated catalyst. It refers that the radical initiated thermal cracking was more dominant at higher temperature, than the catalytic cracking with ionic mechanics.

\subsection{Gases}

Compositions of gases are shown in Figure 4/a and b. Gases contained aliphatic olefins, aliphatic paraffins, branched olefins, and branched hydrocarbons with carbon atoms up to six.

Without catalysts the amount of n-alkanes and nalkenes are $43.5 \%$ and $31.1 \%$ at $500^{\circ} \mathrm{C}$, while these values are $29.5 \%$ and $41.9 \%$ at $600^{\circ} \mathrm{C}$, respectively. It means that higher n-alkane/n-alkene ratio was found at lower temperature, which was the consequence of more dominant reactions at $600^{\circ} \mathrm{C}$. -scission is a well known decomposition mechanism of saturated hydrocarbon chain polymers, leading the formation of vinyl group terminated product. This decomposition route seems more significant at higher temperature. ZSM-5 catalyst increased especially the alkenes content, both branched and non-branched. E.g. the ratio of alkane/alkene was 1.3 and 0.78 at $500^{\circ} \mathrm{C}$ and $600^{\circ} \mathrm{C}$, respectively; which could be decreased to 0.55 and 0.75 , respectively. It is clear that the effect of the catalyst was more significant at lower temperature. The isomerisation of main carbon frame was moderate using ZSM-5. However, significant isomerisation effect was concluded using HZSM-5, because the non-branched/branched ratio could be changed from 4.34 to 1.06 at $500^{\circ} \mathrm{C}$, while from 4.11 to 0.79 at $600^{\circ} \mathrm{C}$ temperature. Therefore the isomerisation effect of HZSM-5 catalyst was more significant at higher temperature.

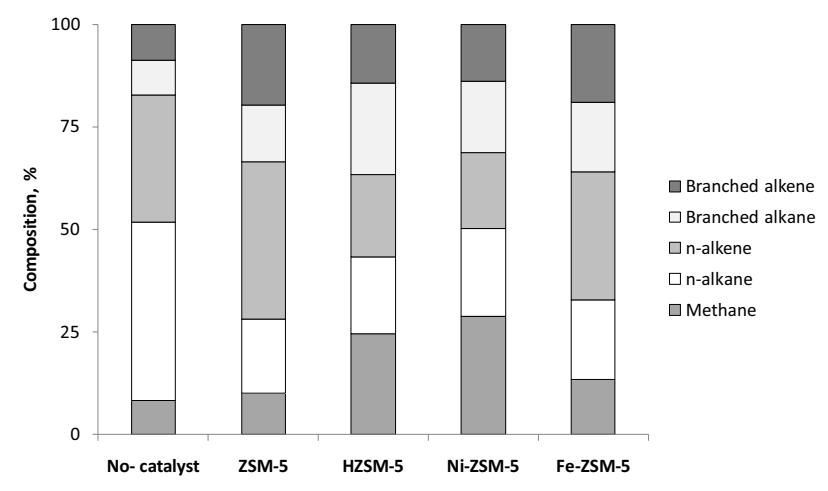

Figure 4/a.Composition of gases at $500^{\circ} \mathrm{C}$ after $25 \mathrm{~min}$ reaction time.

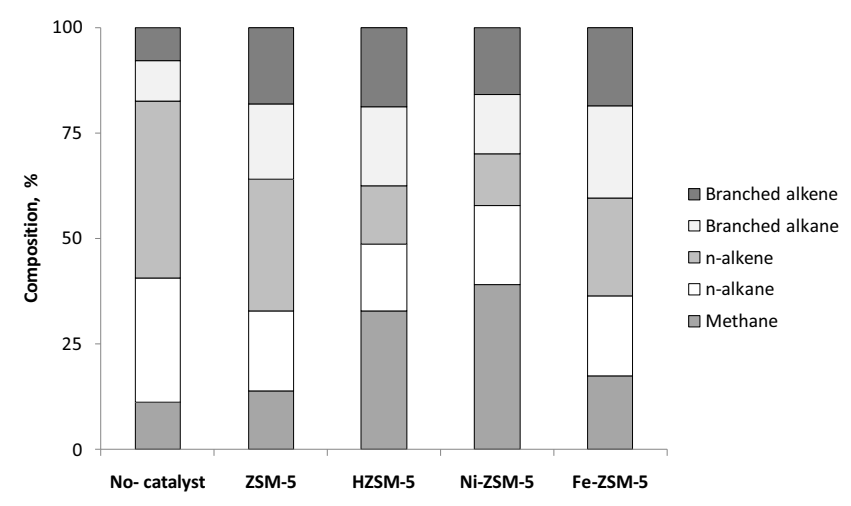

Figure 4/b.Composition of gases at $600^{\circ} \mathrm{C}$ after 15 min reaction time.

Regarding HZSM-5 and Ni-ZSM-5 catalyst, increasing methane concentration was observed at higher temperature. Fe-ZSM-5 catalyst showed also an activity in olefin production reactions, but only at $500^{\circ} \mathrm{C}$, while at $600^{\circ} \mathrm{C}$ the alkane/alkene ratio did not changed significantly comparing to the ratio obtained without catalyst. The methane concentration was $8.2 \%$ and $11.2 \%$ without catalyst at $500^{\circ} \mathrm{C}$ and $600^{\circ} \mathrm{C}$, respectively. Those values could be increased to $28.7 \%$ and $34.7 \%$ by the using of Ni-ZSM-5 catalyst or $24.5 \%$ and $32.9 \%$ using HZSM- 5 catalyst at $500^{\circ} \mathrm{C}$ and $600^{\circ} \mathrm{C}$, respectively.

\subsection{Pyrolysis oil}

The composition of pyrolysis oil was investigated by gaschromatography. The yield of n-alkane, n-alkene, branched alkane, branched alkene, cyclic and aromatic components were summarized, and presented in Figures 5/a and $b$. The pyrolysis oil contained only n-alkane, n- 
alkene, branched alkane and branched alkene when was pyrolysed without catalyst at lower temperature, while $14.2 \%$ aromatics and cyclic compounds was measured in the oil fraction obtained at $600^{\circ} \mathrm{C}$. According to the literature, the cyclization and aromatization reactions became favourable at higher pyrolysis temperatures. In the presence of all investigated catalysts the yields of aromatics, cyclic and branched compounds significantly increased. It is interesting result, that the isomerisation effect of the catalysts was lower at higher temperature. The concentration of branched hydrocarbons obtained without catalyst was $27.9 \%$ and $26.4 \%$ at $500^{\circ} \mathrm{C}$ and $600^{\circ} \mathrm{C}$, respectively. Pyrolysis oils obtained by experiments at $500^{\circ} \mathrm{C}$ contained $41.7 \%, 57.2 \%, 52.2 \%$ and $48.1 \%$ branched compounds using ZSM-5, HZSM-5, Ni-ZSM-5 and Fe-ZSM-5 catalysts, respectively. Using $600{ }^{\circ} \mathrm{C}$ pyrolysis temperatures, that value was $33.1 \%$, $42.5 \%, 40.3 \%$ and $42.9 \%$ following the same catalyst order. It means that the isomerisation efficiency of catalysts was higher at lower temperature. Probably due to the catalyst deactivation, the reaction rate of the thermal cracking was higher, than the rate of the ionic mechanism catalytic reactions at higher temperature. The coke formation is increasing with pyrolysis temperature, and the coke should be deposited on the catalyst surface, decreasing the catalyst activity.

$\square$ Aromatic/Cyclic $\square$ Branched (alkane+alkene) $\square$ n-alkane+n-alkene

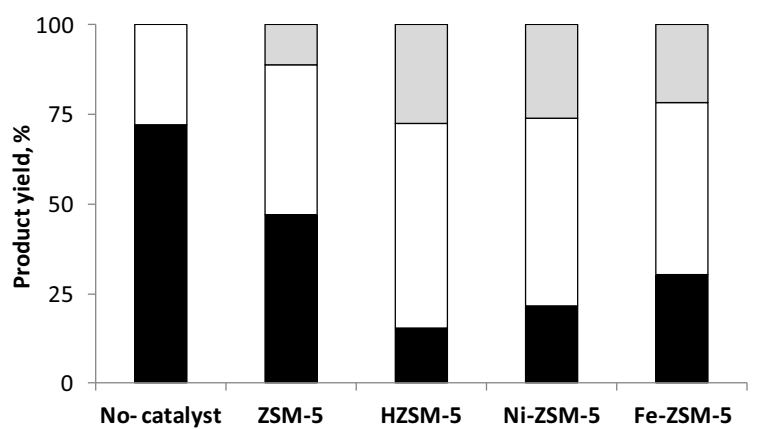

Figure 5/a.Composition of pyrolysis at $500^{\circ} \mathrm{C}$ after $25 \mathrm{~min}$ reaction time.

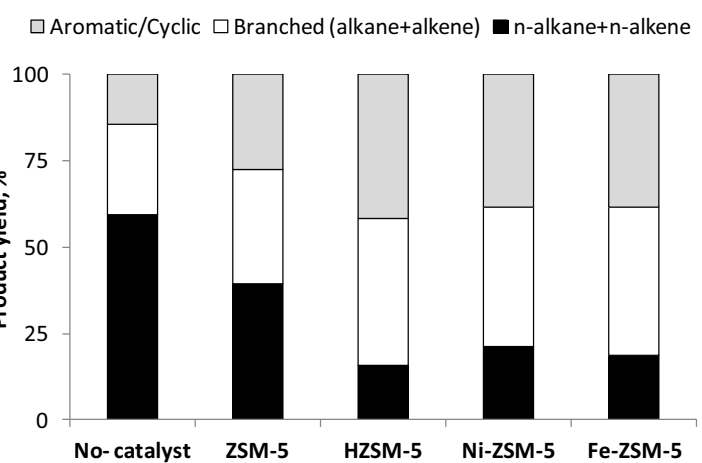

Figure 5/b. Composition of pyrolysis oils at $600^{\circ} \mathrm{C}$ after $15 \mathrm{~min}$ reaction time.

Regarding aromatization it could be concluded, that the concentration of aromatics and cyclic compounds was nearly double at $600^{\circ} \mathrm{C}$, than that of obtained at $500^{\circ} \mathrm{C}$. The highest aromatic content was measured over HZSM-
5 and Ni-ZSM-5 catalysts: $27.3 \%$ and $26.1 \%$ at $500^{\circ} \mathrm{C}$ or $41.6 \%$ and $39.2 \%$ at $600{ }^{\circ} \mathrm{C}$.

Figure 6 shows the ratio of alkanes and alkenes at $500^{\circ} \mathrm{C}$ and $600^{\circ} \mathrm{C}$. As data shows, the ratios of saturated and unsaturated hydrocarbons were 1.64 and 1.19 without catalysts using $500^{\circ} \mathrm{C}$ and $600^{\circ} \mathrm{C}$ pyrolysis temperatures. The ratio of the unsaturated and saturated hydrocarbon yield could be increased by catalysts; especially Ni-ZSM5 catalyst showed high activity in olefin production with ratios of 0.32 (at $500^{\circ} \mathrm{C}$ ) and 0.31 (at $600^{\circ} \mathrm{C}$ ). Transition metal containing catalysts has high activity in hydrogenation/dehydrogenation reactions, therefore alkenes were formed by dehydrogenation reactions of saturated hydrocarbon. Regarding the effect of temperature, results also well show that lower ratio was found at $600^{\circ} \mathrm{C}$, which was caused by the higher formation of olefins by -scission reactions. Especially the catalyst free pyrolysis have resulted significantly lower value of ratio at higher temperature, because it was 1.94 at $500^{\circ} \mathrm{C}$ and 1.19 at $600^{\circ} \mathrm{C}$. This phenomenon was attributed to the cracking of more $\mathrm{C}-\mathrm{C}$ bonds at higher temperature.

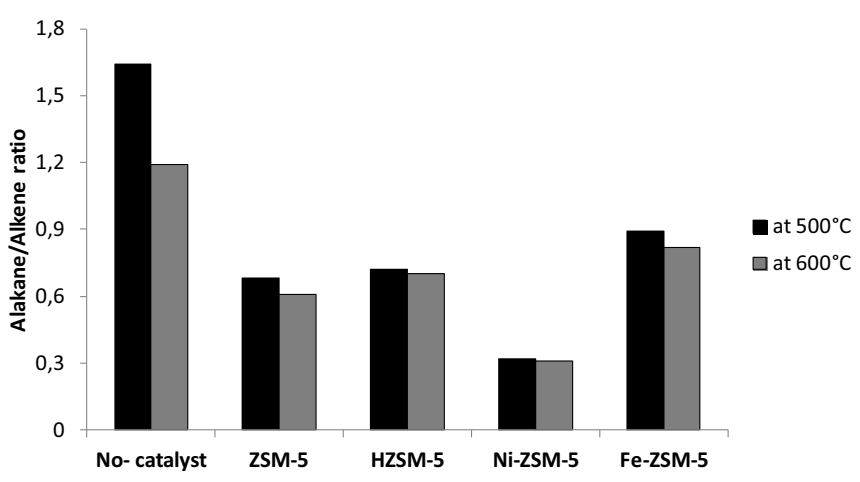

Figure 6. Alkane/alkene ratio.

Other properties of pyrolysis oils are summarized in Table 1, such as density, average molecular weight and boiling point ranges. Based on volatile test, pyrolysis oil contained hydrocarbons in gasoline and middle distillate boiling point ranges $\left(22-331^{\circ} \mathrm{C}\right)$.

Table 1/a. Other properties of pyrolysis oils obtained at $500^{\circ} \mathrm{C}$

\begin{tabular}{|c|c|c|c|c|c|}
\hline Property & $\begin{array}{l}\text { No- } \\
\text { catal } \\
\text { yst }\end{array}$ & $\begin{array}{l}\text { ZSM- } \\
5\end{array}$ & $\begin{array}{l}\text { H- } \\
\text { ZSM } \\
-5\end{array}$ & $\begin{array}{l}\text { Ni- } \\
\text { ZSM- } \\
5\end{array}$ & $\begin{array}{l}\text { Fe- } \\
\text { ZSM- } \\
5\end{array}$ \\
\hline $\begin{array}{l}\text { Density at } \\
20^{\circ} \mathrm{C}, \\
\mathrm{g} / \mathrm{cm}^{3}\end{array}$ & 0.802 & 0.741 & 0.728 & 0.746 & 0.748 \\
\hline $\begin{array}{l}\text { Average } \\
\text { molecular } \\
\text { weight, } \\
\mathrm{g} / \mathrm{mol}\end{array}$ & 221 & 137 & 116 & 142 & 149 \\
\hline \multicolumn{6}{|l|}{$\begin{array}{l}\text { Boiling } \\
\text { points, }{ }^{\circ} \mathrm{C}\end{array}$} \\
\hline IBP & 25 & 25 & 24 & 26 & 22 \\
\hline $50 \%$ & 209 & 157 & 142 & 166 & 168 \\
\hline FBP & 326 & 286 & 287 & 285 & 288 \\
\hline
\end{tabular}


The density of pyrolysis oils was $0.802 \mathrm{~g} / \mathrm{cm}^{3}$ and $0.788 \mathrm{~g} / \mathrm{cm}^{3}$ at 500 and $600^{\circ} \mathrm{C}$. It is clear that more $\mathrm{C}-\mathrm{C}$ bonds of the main carbon chain should be cracked at higher temperature; therefore the density of pyrolysis oil was lower at higher temperature. Catalysts also decreased the average molecular weight of the pyrolysis oils, especially using HZSM-5 catalyst. E.g. without catalyst the average molecular weight was $221 \mathrm{~g} / \mathrm{mol}$, while using HZSM-5 at $500^{\circ} \mathrm{C}$ it decreased to $116 \mathrm{~g} / \mathrm{mol}$. On the other hand both density and molecular weight decreased at $600^{\circ} \mathrm{C}$, comparing to $500^{\circ} \mathrm{C}$ pyrolysis temperature. Similar trend was observed regarding the boiling point ranges, because it was found that larger distillation volume belongs to same boiling points using catalysts than without them.

Table $1 / \mathbf{b}$. Other properties of pyrolysis oils obtained at $600^{\circ} \mathrm{C}$

\begin{tabular}{|c|c|c|c|c|c|}
\hline Property & $\begin{array}{l}\text { No- } \\
\text { cataly } \\
\text { st }\end{array}$ & $\begin{array}{l}\text { ZSM } \\
-5\end{array}$ & $\begin{array}{l}\text { H- } \\
\text { ZSM- } \\
5\end{array}$ & $\begin{array}{l}\text { Ni- } \\
\text { ZSM } \\
-5\end{array}$ & $\begin{array}{l}\mathrm{Fe}- \\
\mathrm{ZSM} \\
-5\end{array}$ \\
\hline $\begin{array}{l}\text { Density at } \\
20^{\circ} \mathrm{C}, \\
\mathrm{g} / \mathrm{cm}^{3}\end{array}$ & 0.788 & 0.735 & 0.722 & 0.730 & 0.738 \\
\hline $\begin{array}{l}\text { Average } \\
\text { molecular } \\
\text { weight, } \\
\mathrm{g} / \mathrm{mol}\end{array}$ & 203 & 124 & 102 & 120 & 126 \\
\hline \multicolumn{6}{|l|}{$\begin{array}{l}\text { Boiling } \\
\text { points, }{ }^{\circ} \mathrm{C}\end{array}$} \\
\hline IBP & 25 & 27 & 22 & 24 & 25 \\
\hline $50 \%$ & 199 & 151 & 137 & 149 & 160 \\
\hline FBP & 331 & 275 & 273 & 278 & 279 \\
\hline
\end{tabular}

\subsection{Heavy oil/Char}

Heavy oil was the bottom product of pyrolysis obtained from the pyrolyis reactor at the end of reaction. This fraction was viscous light or dark brown products. In general they were solid at room temperature, because the melting point was in the range of 39 and $56^{\circ} \mathrm{C}$. Table $2 / \mathrm{a}$ and $2 / \mathrm{b}$ summarizes the main properties of heavy oil obtained by pyrolysis at 500 and $600^{\circ} \mathrm{C}$. Because of more $\mathrm{C}-\mathrm{C}$ scission, heavy oil have lower density, melting point, and flash point obtained at $600^{\circ} \mathrm{C}$, than $500^{\circ} \mathrm{C}$, furthermore the listed properties were also lower using catalysts.

Heating values changed between 40.5 and $41.1 \mathrm{MJ} / \mathrm{kg}$ at $500^{\circ} \mathrm{C}$ or between 41.0 and $41.4 \mathrm{MJ} / \mathrm{kg}$ at $600^{\circ} \mathrm{C}$. It means, that heavy oil had enough high heating values for their further fuel-like utilization, especially for heat, steam or even electricity production. Pyrolysis in the presence of HZSM-5 catalyst resulted the lowest lower density, melting point, and flash point, which was attributed to the cracking reactions on the large surface of HZSM-5 and its high acidity at $500^{\circ} \mathrm{C}$. Experiments over HZSM-5 catalyst at $600^{\circ} \mathrm{C}$ did not result heavy oils product, only char, because the catalyst was too active and fully cracked the polymer main chain.
Table 2/a. Main properties of pyrolysis oils obtained at $500^{\circ} \mathrm{C}$

\begin{tabular}{|c|c|c|c|c|c|}
\hline Property & $\begin{array}{l}\text { No- } \\
\text { cataly } \\
\text { st }\end{array}$ & $\begin{array}{l}\text { ZSM- } \\
5\end{array}$ & $\begin{array}{l}\text { H- } \\
\text { ZSM- } \\
5\end{array}$ & $\begin{array}{l}\text { Ni- } \\
\text { ZSM- } \\
5\end{array}$ & $\begin{array}{l}\text { Fe- } \\
\text { ZSM- } \\
5\end{array}$ \\
\hline Apparence & $\begin{array}{l}\text { Dark } \\
\text { brown } \\
\text { solid } \\
\end{array}$ & $\begin{array}{l}\text { Light } \\
\text { brown } \\
\text { solid }\end{array}$ & $\begin{array}{l}\text { Light } \\
\text { brown } \\
\text { solid }\end{array}$ & $\begin{array}{l}\text { Light } \\
\text { brown } \\
\text { solid }\end{array}$ & $\begin{array}{l}\text { Light } \\
\text { brown } \\
\text { solid }\end{array}$ \\
\hline $\begin{array}{l}\text { Density*, } \\
\mathrm{g} / \mathrm{cm}^{3}\end{array}$ & 0.847 & 0.826 & 0.823 & 0.830 & 0.839 \\
\hline $\begin{array}{l}\text { Melting } \\
\text { point, }{ }^{\circ} \mathrm{C}\end{array}$ & 56 & 51 & 46 & 51 & 53 \\
\hline $\begin{array}{l}\text { Flash } \\
\text { point, }{ }^{\circ} \mathrm{C}\end{array}$ & 208 & 184 & 175 & 179 & 197 \\
\hline $\begin{array}{l}\text { Heating } \\
\text { value, } \\
\mathrm{MJ} / \mathrm{kg}\end{array}$ & 40.9 & 41.1 & 40.5 & 40.7 & 41.0 \\
\hline $\begin{array}{l}\text { Viscosity* } \\
*, \mathrm{~mm}^{2} / \mathrm{s}\end{array}$ & 5.2 & 4.5 & 4.2 & 4.3 & 4.4 \\
\hline
\end{tabular}

* at $20^{\circ} \mathrm{C},{ }^{* *}$ at $70^{\circ} \mathrm{C}$

Table $2 / \mathbf{b}$. Main properties of pyrolysis oils obtained at $600^{\circ} \mathrm{C}$

\begin{tabular}{|c|c|c|c|c|}
\hline Property & $\begin{array}{l}\text { No- } \\
\text { catalyst }\end{array}$ & $\begin{array}{l}\text { ZSM- } \\
5\end{array}$ & $\begin{array}{l}\text { Ni- } \\
\text { ZSM-5 }\end{array}$ & $\begin{array}{l}\text { Fe- } \\
\text { ZSM- } \\
5\end{array}$ \\
\hline Apparence & $\begin{array}{l}\text { Light } \\
\text { brown } \\
\text { solid }\end{array}$ & $\begin{array}{l}\text { Light } \\
\text { brown } \\
\text { solid }\end{array}$ & $\begin{array}{l}\text { Light } \\
\text { brown } \\
\text { solid }\end{array}$ & $\begin{array}{l}\text { Light } \\
\text { brown } \\
\text { solid }\end{array}$ \\
\hline $\begin{array}{l}\text { Density*, } \\
\mathrm{g} / \mathrm{cm}^{3}\end{array}$ & 0.831 & 0.801 & 0.914 & 0.809 \\
\hline $\begin{array}{l}\text { Melting } \\
\text { point, }{ }^{\circ} \mathrm{C}\end{array}$ & 45 & 39 & 39 & 40 \\
\hline $\begin{array}{l}\text { Flash } \\
\text { point, }{ }^{\circ} \mathrm{C}\end{array}$ & 195 & 189 & 187 & 190 \\
\hline $\begin{array}{l}\text { Heating } \\
\text { value, } \mathrm{MJ} / \mathrm{kg}\end{array}$ & 41.0 & 41.1 & 41.4 & 41.2 \\
\hline $\begin{array}{l}\text { Viscosity**, } \\
\mathrm{mm}^{2} / \mathrm{s}\end{array}$ & 4.6 & 3.8 & 3.6 & 3.7 \\
\hline
\end{tabular}

$*$ at $20^{\circ} \mathrm{C}, * *$ at $70^{\circ} \mathrm{C}$

\section{Conclusion}

Waste plastics from ELV dismantling have been pyrolyzed in a continuously stirred batch reactor at 500 and $600^{\circ} \mathrm{C}$ using different catalysts.

- Significant increasing in gases and pyrolysis oils was found using modified ZSM-5 catalysts. HZSM-5 catalyst had high activity in formation of gaseous product.

- High concentration of methane was found using HZSM-5 and Ni-ZSM-5 catalysts.

- Mainly branched hydrocarbons were obtained over HZSM-5 catalyst, which was the consequence of the isomerization effect.

- ZSM-5 and Fe-ZSM-5 catalyst had high activity in formation of unsaturated hydrocarbons.

- The pyrolysis oil contained n-alkane, n-alkene, branched alkane, branched alkene, cyclic and aromatic hydrocarbons, and the composition was affected by 
catalysts, especially the aromatic and branched hydrocarbon content could be increased.

\section{Acknowledgment}

The authors acknowledge to the National Office for Research and Innovation (NKTH), assistance granted under the Hungarian-Indian (KTIA-DST) R\&D\&I Program (TÉT_13_DST-1-2014-0003).

\section{References}

1. A. López, I. de Marco, B. M. Caballero, M. F. Laresgoiti, A. Adrados, A. Torres, Waste Manage, 31, 1973 (2011)

2. S. S. Lam, A. D. Russell, C. L. Lee, H. A. Chase, Fuel, 92, 327 (2012)

3. R. Aguado, G. Elordi, A. Arrizabalaga, M. Artetxe, J. Bilbao, M. Olazar, Chem. Eng. J. 254, 357 (2014)

4. M. K. Harder, O.T. Forton, J. Anal. App. Pyrol., 79, 387 (2007)
5. P. T. Williams, S. Besler, D. T. Taylor, Fuel, 69, 1474 (1990)

6. http://www.idis2.com/ (downloaded at 10 Nov. 2015)

7. http://www.gov.scot/Publications/2013/12/9124/9 (downloaded at 10 Nov. 2015)

8. http://www.nist.gov/lightweighting/ncalfeature.cfm (downloaded at 10 Nov.2015)

9. S. S. Lam, A. D. Russell, C. L. Lee, S. K. Lam, H. A. Chase, Intern. Journal of Hydrogen Energ., 37, 5011 (2012)

10. J. H. Chen, K. S. Chen, L. Y. Tong, J. of Hazard. Mat., 84, 43 (2001)

11. J. D. Martínez, J. Rodríguez-Fernández, J. SánchezValdepeñas, R. Murillo, T. García, Fuel, 115, 490 (2014)

12. B. Plage, A-D. Berg, S. Luhn, Foren. Science Intern., 177, 146 (2008)

13. P. Kusch, V. Obst, D. Schroeder-Obst, W. Fink, G. Knupp, J. Steinhaus Eng. Failure Analysis, 35, 114 (2013)

14. J. Zięba-Palus, G. Zadora, J. M. Milczarek, P. Kościelniak, J. of Chrom. A, 1179, 41 (2008) 